\title{
E-Approval Plans in Research Libraries
}

\section{Carmelita Pickett, Simona Tabacaru, and Jeanne Harrell}

\begin{abstract}
Research libraries have long invested in approval plan services, which offer an economical way to acquire scholarly and scientific publications. Traditional approval plans have evolved and now enable libraries to expand their e-book offerings to better serve researchers. Publishers offer a myriad of e-book purchasing options. These range from individual titles to comprehensive packages allowing libraries to choose publisher-direct (Springer and others) or aggregator (Ebrary, for example) access, but a standard access and pricing model is needed to promote systematic acquisition of e-books. In 2010, Texas A\&M University Libraries implemented an e-preferred approval plan. This article will discuss the evaluation process for research libraries migrating to an e-preferred approval plan.
\end{abstract}

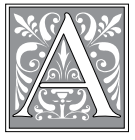

pproval plan services have evolved as technological advances influence user expectations; approval vendors now include digital content in their offerings. These expanded services support a variety of access models for monographs that accentuate shifting collection development initiatives in research libraries. Libraries have the option of incorporating e-books in approval plans by adopting hybrid profiles accommodating both print and digital content. Research libraries have long suspected that print collections are little used, as hypothesized in a 1979 study assessing the University of Pittsburgh's print collection. ${ }^{1}$ Most recently, a 2010 study by the Cornell University Libraries (CUL) Collection Development
Executive Committee on Print Collection Usage revealed that only 45 percent of CUL-held titles published since 1990 had circulated at least once, while 55 percent of these titles had never circulated. ${ }^{2}$ This study reinforces what many research libraries know about their own print collections through evidence-based assessment or anecdotal evidence: the use of print collections is declining. Expansion of ebook offerings seems a logical alternative to investing only in print collections.

The e-book marketplace has not been easy to navigate as publishers struggle to define appropriate business models. During the late 1990s, publishers and aggregators only offered libraries backlist titles of content they already owned in print, ${ }^{3}$ making it difficult for libraries with

Carmelita Pickett is Head of Collection Development Operations \& Acquisitions Services, Simona Tabacaru is Development Relations Specialist, and Jeanne Harrell is Coordinator of Monograph $\mathcal{E}$ Automated Acquisitions, all at Texas AEM University Libraries; e-mail: cpickett-k@library.tamu.edu, stabacaru@library. tamu.edu, jeanneh@library.tamu.edu. (C) 2014 Carmelita Pickett, Simona Tabacaru, and Jeanne Harrell, Attribution-NonCommercial (http://creativecommons.org/licenses/by-nc/3.0/) CC BY-NC 
tightened budgets to justify purchasing duplicate content. In the current marketplace, publishers continue to struggle with managing front-list titles, typically releasing e-book versions after titles have been in print for up to several months in an attempt to maintain their print revenue stream while building digital revenue. This practice illustrates indecisiveness in the publishing industry about the best business models for their content as they attempt to market e-books to consumers and libraries. Some publishers embargo e-book content from aggregators in an effort to promote their platforms and direct purchasing. This practice forces libraries to invest in both aggregator and publisher direct content. Publisher's Digital Rights Management (DRM) is also a challenge; most publishers prohibit interlibrary loan, and there are problems with unclear copyright, perpetual access, and preservation provisions for purchased e-book content. Even considering these challenges, research libraries still make significant investments in e-book collections. Given the long history of approval plan activity in research libraries, libraries should have the flexibility to manage e-book purchases through existing approval plans, taking advantage of the cost effectiveness of approval plans, profiles, and streamlined workflow.

\section{Background}

Texas A\&M University (TAMU) is a land, space, and sea grant institution, founded in 1876 as the state's first public institution of higher education, serving nearly 50,000 students in over 120 undergraduate and 240 graduate degree programs in ten colleges. As a land grant institution, TAMU Libraries' collection strengths include agriculture, science disciplines, and engineering. In 2003, TAMU Libraries embraced a strategic directive to acquire e-content whenever possible to enhance user access to scholarly content. In keeping with this mandate, the Acquisitions Department began to initiate a number of e-content arrangements with traditional
Science Technology Engineering \& Medicine (STEM) and Humanities \& Social Science (HSS) publishers. In addition, in 2006 the library revamped its fund-based acquisitions model and migrated from Blackwell to YBP for its approval plan services. ${ }^{4}$ The library also reinstated collection development policy statements. ${ }^{5}$ By 2009, when TAMU Libraries celebrated its 4 millionth volume, collection expenditures were $\$ 11,398,282$ for recurring electronic resources (electronic journals and databases) and $\$ 4,650,822$ for monographic expenditures. ${ }^{6}$ The monographic expenditures included $\$ 3,799,788$ for patron-initiated requests and approval plan books.

\section{Literature Review}

In the early 1960s, Richard Abel \& Co. developed a cost-efficient way for research libraries to acquire large quantities of scholarly and scientific books. This development, known as the approval plan, continues to play an integral role in the acquisition of books for libraries in the United States and abroad. Approval plans were "designed to both streamline the process and reduce internal costs incurred by libraries in acquiring the vast bulk of in-print titles published in the major scholarly languages each year."7 Libraries can specify cost limits, classification range, language, format type, and audience level; these parameters help build what is known as the approval profile. Approval profiles are designed to match a library's specific collection requirements with a wide range of published content. Since its adoption by research libraries over fifty years ago, the approval plan continues to be the most accepted and widely used means of acquiring monographs, mitigating the burdensome cost and time associated with title by title purchasing.

The status of approval plans in the United States is well documented. In 1997, the Association of Research Libraries (ARL) assessed the status and evolution of approval plans in research libraries. The 
study revealed that libraries were experiencing financial challenges due to serials inflation and dollar value fluctuation. Despite this challenging environment, many research libraries still supported the approval plan. Approval plans allowed research libraries to stretch their monographic budgets while redirecting funds to support escalating serial subscriptions, a trend that continues today. The ARL study also highlighted common benefits echoed among research libraries rationalizing their continued use of approval plans. These benefits include quick receipt of materials, discounts, staff savings in processing materials, and improved collection development. ${ }^{8}$ In addition, approval plans required less attention from subject selectors, freeing them to engage in other liaison activity. A 2008 study assessing the status of approval plans in college libraries revealed that, despite discussions about the decline of the scholarly text, approval plan use in college libraries was not declining but the number of titles acquired on approval was declining due to inflation and electronic resources. The author summarized that there was no indication that the approval plan had "diminished in its usefulness." ${ }^{9}$ In a more recent approval plan study assessing the approval plan profiles of two large ARL libraries, the authors determined that consistent review of approval profiles is "necessary to ensure adjustments occur based on user needs and fiscal constraints."10

Approval plans have also met with criticism. One study suggested that the approval plan process can be disruptive to the acquisitions workflow. ${ }^{11}$ In this study, the author cited the work required by staff and librarians to return duplicate and marginal titles. ARL's 1997 study also revealed other approval plan shortcomings, such as minimal coverage of small presses and inadequate profiling. ${ }^{12}$ Fenner noted that the approval plan is a form of outsourcing, which shifts selection responsibilities from librarians to vendors and cited vendor lack of knowledge of local collections and users as a shortcoming of approval plans. ${ }^{13}$ All three studies found that the approval plan is not a perfect tool, but it remains the predominant means by which research libraries acquire monographs in bulk.

While approval plans are well established for print materials, they have proven less effective in integrating ebooks on a large scale. There are relatively few studies that specifically address the implementation of e-book approval plans in research libraries.

Many academic institutions have acquired e-books directly from publishers, aggregators, or e-book vendors through firm orders, standing orders, subscriptions, and, more recently, through payper-view or patron-driven selection. In addition to these acquisition methods, some authors debate the idea of successfully integrating e-books into the approval process. A number of relevant research studies focus on the benefits and challenges of acquiring e-books through approval plans. Supporters of e-book approval plans are unanimous in affirming that one of the major benefits is enabling libraries to manage duplication between electronic and print formats. ${ }^{14}$ Levine-Clark identifies additional reasons why research libraries should consider integrating e-books into existing print approval plans; the systematic acquisition of e-books, the format control, and the potential for significant price discount for the purchase of both print and electronic versions of a given title. ${ }^{15}$ Buckley and Tritt mention as a significant benefit the opportunity for subject selectors to preview the full text of e-books prior to purchase and to reject titles profiled on the approval plan; this benefit also provides opportunities to refine and adjust the approval plan. ${ }^{16}$ Hodges et al. provide general reasons for "e-book-preferred policies" such as meeting the expectations of users who increasingly prefer to "interact virtually with information and desire the convenience of remote 24/7 access," and addressing space and storage 
constraints experienced by many research libraries. ${ }^{17}$

Although the benefits of e-approval plans are notable, a number of significant challenges obstruct the development of e-book approval plans to their full potential. One major drawback is that e-book coverage in some subject areas is still limited compared to the broad availability of print titles. ${ }^{18}$ Another factor that restricts the comprehensiveness of e-book approval plans is the publication timelag between release of print books and their electronic counterparts. ${ }^{19}$ Herther's study cites Ann-Marie Breaux, the Vice President of Academic Service Integration for YBP Library Services, who states that simultaneous offering of e-book and print titles on approval profiles "is about $20-25 \%$ of new titles." ${ }^{20}$ The lack of simultaneous print and e-book publication is a concern raised by many academic research librarians when negotiating with e-book providers. Lately, librarians have observed more publishers start releasing e-books concurrently and even prior to their print versions. According to van der Velde and Ernst, "Springer publishes over 4,000 book titles annually, which are converted into e-books almost without exception." ${ }^{21}$ Some major publishers, including Elsevier, Springer, Wiley, and Taylor \& Francis, provide much of their content to multiple e-book aggregators and vendors, but some publishers make their electronic titles available only to selected vendors, making it difficult for libraries to obtain complete subject coverage unless they work with multiple ebook vendors. ${ }^{22}$ Publishers who embargo electronic content for a period of time after the print version is released create a barrier to the full integration of e-books into approval plans and the "lack of a sustainable pricing model" may impede the systematic and consistent acquisition of e-books by some libraries. ${ }^{23}$

Libraries that choose to integrate print and e-book approval plans need to take these challenges into consideration and adapt acquisition workflows and collec- tion management policies to optimally serve researchers. Recent library literature suggests that e-book approval plans are gaining momentum in academic institutions but are still in developmental stages. Buckley and Tritt discuss a pilot e-book approval plan initiated by a private academic institution, Nova Southeastern University (NSU). During the fiscal year 2008-2009, NSU's Alvin Sherman Library undertook a pilot, which ran in parallel with a print approval plan and was based on library-selected publishers within a limited set of disciplines: education, psychology, computer science, and library science. According to the authors, the e-book approval plan integrated well into "existing collection development and acquisitions workflows" and was beneficial for quickly meeting user needs, particularly distance education students. ${ }^{24}$

The increased acceptance and preference of the TAMU community for e-books prompted the TAMU Libraries to implement an e-preferred approval plan. This article will discuss the evaluation process for research libraries migrating to an epreferred approval plan.

\section{TAMU Libraries Research Studies}

Longitudinal studies help libraries assess services and collections over a period of time, making it easier to identify trends. Since 2000, TAMU Libraries has administered the LibQUAL+® survey to undergraduate students, graduate students and faculty in order to assess programs, collections, and services. LibQUAL+® surveys are administered annually to undergraduate and graduate students, while faculty members are surveyed every two years.

The survey consists of 22 questions and a free-text comment box and includes demographic, satisfaction, and five outcome questions. The free-text comment box permits respondents to suggest improvements or express concerns about library services. The library service quality is measured on three dimensions: affect of service (the emotive aspects of provided 
service); information control (scope of content and means of access to content), and library as a space (physical characteristics of library space). The information control answers can be used to assess user satisfaction with library collections, as shown in Cook and Maciel's 2010 study in which the authors summarize the Spring 2010 LibQUAL+® survey results, highlighting the top priorities, areas of excellence, and areas of concern. ${ }^{25}$ In this study, TAMU graduate students identified "Making electronic resources accessible from my home and office" and "Print and/or electronic journal collections I require for my work" as two of the top five priorities. Additionally, the graduate students identified "Making electronic resources accessible from my home and office," "The electronic information resources I need," and "Print and/or electronic journal collections I require for my work" as three of the top five areas of concern. Faculty survey data were comparable to the graduate students' survey results, with "The electronic information resources I need" and "Print and/ or electronic journal collections I require for my work" being identified as two of the top priorities, areas of excellence, and areas of concern. Faculty also indicated "Making electronic resources accessible from my home or office" a top priority and area of concern.

While these LibQUAL+ ${ }^{\circledR}$ survey results revealed that digital resources were preferred by the TAMU user community, there was no distinction between preference for e-journals, databases, and e-books. Collections personnel correlated these results with those provided by additional TAMU e-book use research studies.

A study conducted by other librarians at TAMU Libraries examined usage patterns of Safari e-books compared to their print equivalents at TAMU. ${ }^{26}$ The authors compared electronic and print usage during fall 2006 and spring 2007. The study revealed that the Safari e-books that were used "were accessed between 1 and 1040 times for an average of 40, while the print books in the QA75-76.9 call number ranges, with the same publication dates that were checked out, circulated between 1 and 44 times for an average of 1.9 times." When the most frequently accessed Safari e-book was compared to its print counterpart, the e-book access to the print checked out ratio was 1,040 to 3. This study proves that TAMU Libraries' users prefer e-books over their print counterparts at least in the computer science discipline.

In another relevant study conducted by TAMU librarians in 2007, the authors compared usage data between equivalent e-books and print books owned by the TAMU Libraries in the physical sciences and technology. ${ }^{27}$ The top ten most used ebooks from NetLibrary (currently Ebsco), Ebrary, and Safari were identified and compared to print book use. The authors found that, for the top 10 NetLibrary ebook titles in the physical sciences and technology, the ratio of e-book use to print use was 6.2 to 1 ." The ratio of the top 17 Ebrary e-book use to print use was 17 to 1 and of the ratio of the top 10 Safari e-books use to print use was over 200 to 1 . On average, "the physical science e-books that were accessed were used at least 3.5 times as much as the corresponding print titles" that were checked out. Additionally, the authors discovered a significant growth in the use of some recently acquired e-book collections, such as the CRC Press e-books and Knovel.

After correlating LibQUAL+® survey results with those reported in these locally focused TAMU Libraries e-book use studies, collections personnel were certain about the increased acceptance and preference of the libraries' user community for e-books. Building on this strong evidence of preference for electronic, acquisitions and collection staff proceeded to the next step in this process. Since the libraries made significant investments in comprehensive and subscription e-book agreements, analyzing these agreements to determine duplication would be necessary before implementing an e-preferred approval plan. 


\section{Assessment: Duplication \& Publishers List}

During the summer of 2010, the Head of Collection Development Operations at TAMU Libraries began planning for a 13 percent budget deficit. As part of the planning, it seemed appropriate to evaluate the approval plan services then in place for effectiveness and efficiency. The goals of the evaluative process were three-fold: to determine if the library could trim the approval expenditure by $\$ 800,000$, expand the approval profile to include e-books and evaluate existing e-book agreements with publishers and aggregators. The $\$ 800,000$ represented 40 percent of the overall mandated $\$ 2$ million collection budget reduction. After discussions with YBP, the TAMU Libraries approval plan vendor, collections personnel determined that an e-preferred approval profile would allow the library to decrease the number of print monographs on approval, lessen the number of print monographs received on approval and repurpose space for library users. Moving to an e-preferred approval profile would permit subject selectors greater transparency in discovering e-books published in their specific subject area and assess discipline-specific areas where print monographs would still be the preferred format. Finally, it would allow collections personnel to integrate e-books into the existing e-book workflow, guide future e-book purchasing within the framework of the carefully calibrated approval profile, and reconsider or possibly rework preexisting comprehensive e-book agreements. See table 1 for a list of some TAMU Libraries e-book agreements.

The implementation of the e-preferred approval plan was preceded by an intensive review of the approval plan by collections personnel from July through October 2010. Since budget cuts were on the horizon, collections personnel began first by examining aspects of the approval plan to formulate specific directives to guide communication between subject selectors and the YBP representative. Col-

\begin{tabular}{|c|c|}
\hline \multicolumn{2}{|c|}{$\begin{array}{c}\text { TABLE } 1 \\
\text { TAMU Libraries E-book Content } \\
\text { Providers }\end{array}$} \\
\hline E-Book Content Providers & Access \\
\hline CAB International & $\mathrm{PD}, \mathrm{C}$ \\
\hline CRC Press & PD \\
\hline EBL & $\mathrm{A}$ \\
\hline Ebrary & A \\
\hline Elsevier & $\mathrm{PD}, \mathrm{C}$ \\
\hline $\begin{array}{l}\text { Ebsco eBook Collection } \\
\text { (formerly Netlibrary) }\end{array}$ & $\mathrm{A}$ \\
\hline Emerald & $\mathrm{PD}$ \\
\hline Knovel & A \\
\hline Morgan \& Claypool & $\mathrm{PD}$ \\
\hline Oxford University Press & $\mathrm{PD}$ \\
\hline PsycBOOKS & A \\
\hline Safari & A \\
\hline Sage & $\mathrm{PD}$ \\
\hline Springer & $\mathrm{PD}, \mathrm{C}$ \\
\hline Taylor \& Francis & $\mathrm{PD}$ \\
\hline Wiley & $\mathrm{PD}, \mathrm{C}$ \\
\hline $\begin{array}{l}\text { Key: } \mathbf{P D}=\text { Publisher-Direct } \\
\mathrm{A}=\text { Aggregator, } \mathrm{C}=\mathrm{Compr}\end{array}$ & nsive \\
\hline
\end{tabular}

lections personnel examination of the approval plan included a review of current and previous fiscal year expenditures, the approval plan publisher list, the parameters influencing the profile, and TAMU Libraries collection development policies.

Collections personnel ran customized reports in Global Online Bibliographic Information (GOBI3), the YBP online interface, to determine historical and current approval plan expenditures. These expenditure reports included the overall expenditure based on TAMU Libraries' previous fiscal year and current fiscal year expenditure for specific call numbers. In addition, a report detailing over 1,300 publishers profiled on the approval plan was analyzed to determine profiled publishers, purchase orders submitted based on GOBI's online notifications, and net 


\begin{tabular}{|c|c|}
\hline \multicolumn{2}{|c|}{$\begin{array}{c}\text { TABLE } 2 \\
\text { Library of Congress Targets }\end{array}$} \\
\hline $\begin{array}{l}\text { LC Call Number } \\
\text { Targets }\end{array}$ & $\begin{array}{c}\text { Fiscal Year } 2010 \\
\text { Expenditure }\end{array}$ \\
\hline B - Philosophy & $\$ 168,616.02$ \\
\hline $\begin{array}{l}\text { D - History, Eastern } \\
\text { Hemisphere }\end{array}$ & $\$ 120,996.08$ \\
\hline $\mathrm{H}$ - Social Sciences & $\$ 336,634.89$ \\
\hline $\mathrm{K}-\mathrm{Law}$ & $\$ 40,357.69$ \\
\hline $\mathrm{N}$ - Visual Arts & $\$ 119,570.81$ \\
\hline $\mathrm{Q}$-Science & $\$ 251,425.54$ \\
\hline $\mathrm{T}-$ Technology & $\$ 228,994.97$ \\
\hline Z-Library Science & $\$ 47,538.02$ \\
\hline
\end{tabular}

titles acquired on approval. After reviewing these figures, collections personnel developed a list of call number ranges to target (see table 2) for the approval plan review and analyzed collection development policies to determine if the level of expenditure for specific disciplines were justified when considering the degree programs defined in the collection development policy statements. These factors guided conversations with subject selectors to ensure that the current expenditures for these areas were appropriate to support the current TAMU curricula.

Once the targets were identified, collections personnel transitioned to analyzing the approval plan publishers list in more detail. Collections personnel ran reports in GOBI3 to review the publisher output for the current profile. After reviewing this lengthy document, it was determined that additional investigation was warranted. Collections personnel wanted to determine the extent of duplication between

existing comprehensive and subscription e-book agreements. Second, they wanted to determine the number of publishers for which no discount was given and, third, work with subject selectors to determine possible publishers to block because of marginal content. Blocking a publisher on the approval plan means that no books or book notifications are received for that particular publisher. In the final analysis, in consultation with subject selectors, collections personnel initiated the following publisher changes to the profile. The publisher profile was modified by slipping 167 publishers and blocking 30 publishers. When a publisher is "slipped" on the approval plan, books by that publisher are not sent automatically on approval; instead, online notifications are generated in GOBI3 and sent to subject selectors, who review the books on notifications and make selection decisions. Of the 167 publishers, 132 were slipped because no discounts were given, 26 were covered by an existing e-book deal, and 9 were determined to provide marginal content. Of the 30 blocked publishers, 5 provided no discount, 24 were covered by an existing e-book deal, and one provided marginal content. Table 3 illustrates the number of approximate titles acquired with the comprehensive e-book agreements.

These blocks would prevent duplication with existing comprehensive e-book agreements. In addition, the collections personnel determined that slipping 132 publishers, representing 15 to 25 percent of the approval plan expenditure, would prove to be the most significant modification to achieve the $\$ 800,000$ budget reduction requested by library administration.

\begin{tabular}{|l|c|c|c|c|c|c|c|}
\hline \multicolumn{7}{|c|}{ TABLE 3 } \\
Number of E-books Acquired with Comprehensive Agreements \\
\hline $\begin{array}{l}\text { Pub- } \\
\text { lisher }\end{array}$ & $\begin{array}{c}\text { \# Titles } \\
\text { Pre-2007 }\end{array}$ & $\begin{array}{c}\text { \# Titles } \\
\mathbf{2 0 0 7}\end{array}$ & $\begin{array}{c}\text { \# Titles } \\
\mathbf{2 0 0 8}\end{array}$ & $\begin{array}{c}\text { \# Titles } \\
\mathbf{2 0 0 9}\end{array}$ & $\begin{array}{c}\text { \# Titles } \\
\mathbf{2 0 1 0}\end{array}$ & $\begin{array}{c}\text { \# Titles } \\
\mathbf{2 0 1 1}\end{array}$ & Total \\
\hline Elsevier & 119 & 532 & 433 & 363 & 426 & 427 & 2,300 \\
\hline Springer & 6,374 & 3,409 & 3,507 & 4,000 & 3,951 & 4,702 & 25,943 \\
\hline Wiley & 866 & 427 & 407 & 2,060 & 1,186 & 970 & 5,926 \\
\hline
\end{tabular}


There were other advantages to slipping these publishers; these included increased oversight by collections personnel and subject selectors and fewer titles received on approval automatically. Subject selectors could still be notified about titles of interest and could purchase these titles for the collection as needed.

After organizing the approval plan data, collections personnel could coordinate the evaluation with the subject selectors and provide some considerations to guide discussions during the scheduled meetings to review all profiles with the YBP representative. Prior to these mandatory meetings, collections personnel requested that subject selectors review their collection development policy statements. This was essential to the overall evaluative process since this was the first year the library could fully integrate the collection development policy statements in a tangible assessment project. Selectors were asked to consider the collecting levels for their specific areas and correlate these factors with existing masters' and doctoral programs. During the review with the YBP representative, collections personnel discovered that, in many instances, subject selectors had implemented or requested some profile changes but there were structural features of the approval plan that acted to override these requests. After additional conversations with the YBP representative, it was disclosed that the following hierarchy influences the approval plan. The first influence is series, then publishers and nonsubject parameters, and, last, Library of Congress call number classification. Understanding this hierarchy enabled collections personnel and subject selectors to better comprehend how the profile worked. It explained why exceptions were overridden during previously requested profile modifications and also explained inconsistent expenditures in specific call number ranges despite attempts to target those areas. Addressing the publishers list would prove to be one of the most important factors assessed during the evalua- tive process. Once collections personnel compiled all the changes necessary to achieve the $\$ 800,000$ budget reduction for the approval plan, incorporated requests from subject selectors, and finalized a list of blocked and slipped publishers, it was easy to transition to an e-preferred plan.

\section{E-Preferred Approval Plan Implementation}

An e-preferred approval plan simply means that, whenever possible, the library would prefer an e-book but a print copy is acceptable. If an e-book is released in six to eight weeks following its print counterpart, then the library will receive these titles as e-books. Since the e-preferred plan is based on the approval plan profile, only titles specified by the library profile would appear. An e-only plan would eliminate print monographs and would not provide broad coverage needed to support TAMU curricula. Setting up the e-preferred profile was relatively simple, requiring little more than determining access options and e-book providers for the plan. The choices available were Ebrary MUPO (multiuser), Ebrary SUPO (single user), EBL Unlimited (no restrictions on the number of loan instances or number of simultaneous users allowed), EBL Non Linear (multiuser, allows up to 325 loan instances per year), and EBL Textbook (access limited to maximum three simultaneous users). TAMU Libraries' e-preferred plan was initially set up with Ebrary as the first choice, since Ebrary's e-book inventory was extensive and usage statistics for current collections on the Ebrary platform indicated frequent use. Collections personnel speculated that expanding the titles available on the platform would be well received by users. Netlibrary had been acquired by EBSCO at this point, but the online management system was not yet operational so the library had to set up a license to acquire Netlibrary titles through YBP. Since the library had initiated many e-book agreements with individual publishers and set up licenses with aggregators prior to 


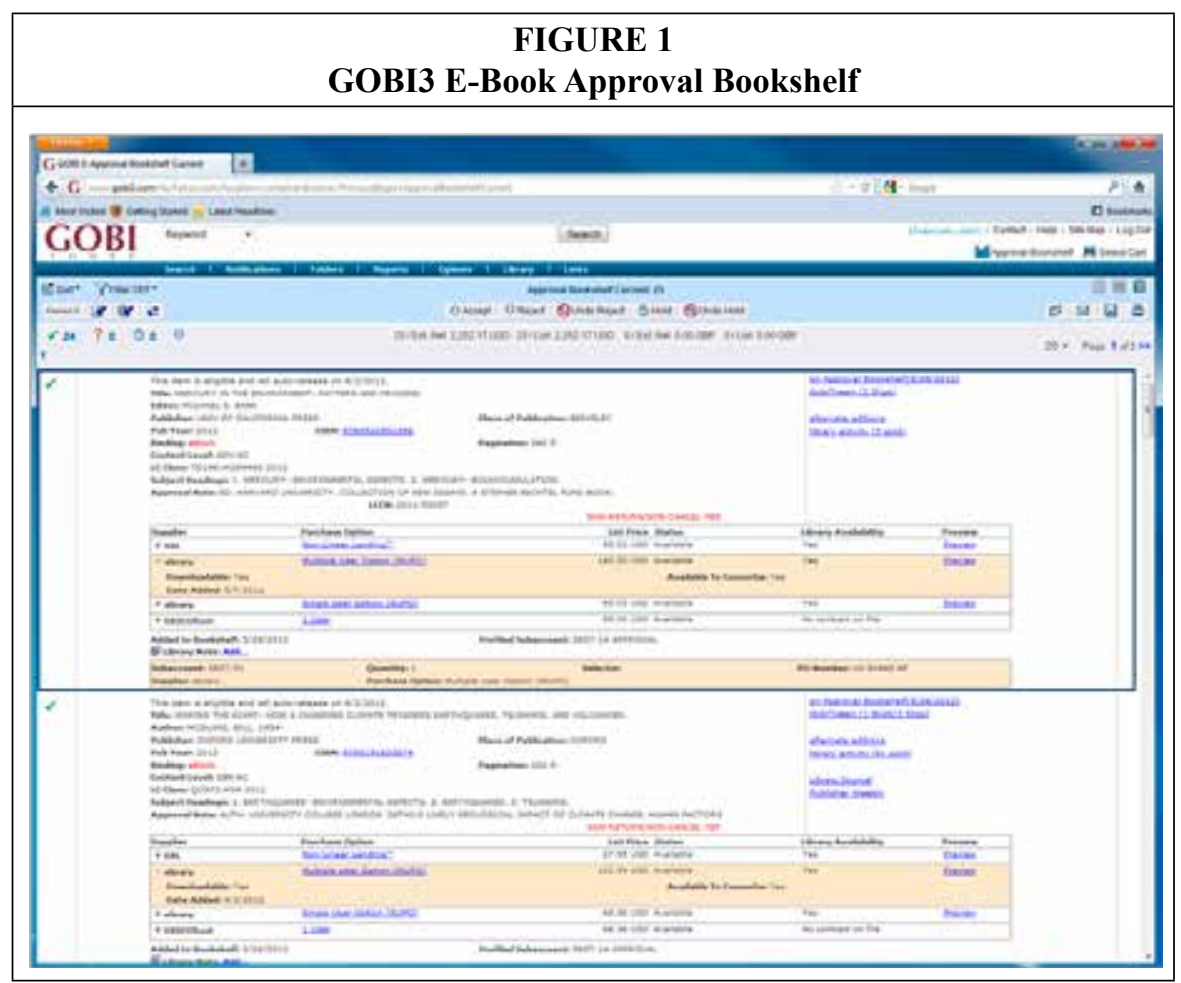

transitioning to an e-preferred plan, there was no delay in purchase when the first e-book was identified by the approval profile. TAMU Libraries serve a large user population, so selecting the multiple user option (MUPO) when available was more advantageous for the e-preferred plan.

YBP's online interface, GOBI3, made review of the e-preferred "Approval Bookshelf" titles released each weekend quite straightforward. The user logs into GOBI3, selects the Approval Bookshelf, and can review each title with all of its descriptive metadata.

Subject selectors and collections personnel have one week (Saturday to Friday) to either "Accept" a title for immediate purchase; "Reject" a title (which allows the user to give the reason for others who might view the title record); "Undo Reject" (if a decision is reversed by the original user or another user); "Hold" (which will put the title on hold for 90 days), and "Undo Hold." If no action is taken to either reject or put a title on hold, titles are automatically purchased on Saturday of each week. After a title has been on hold for 90 days with no action, it is dropped from the Approval Shelflist. Titles in the Approval Shelflist can be sorted and filtered.

The TAMU Libraries had previously developed a workflow for e-book availability notifications and loading bibliographic records into Voyager, so purchased e-preferred plan titles became included in that process. Collections and cataloging personnel received notification of e-preferred purchases and made titles accessible within a week.

\section{Discussion}

Research libraries contemplating the viability of an e-preferred approval plan should invest in thorough examination of both their approval plan and existing e-book agreements with aggregators and publishers. Duplication is an ongoing concern for research libraries attempting to achieve some balance in their ability 
to respond to evolving user needs while carefully monitoring constricted budgets. After the approval plan evaluation, TAMU Libraries achieved its initial goals to trim the approval plan budget, evaluate the sustainability of existing comprehensive e-book agreements, and implement an e-preferred approval plan.

As libraries are tasked with stretching budgets to maintain research collections, approval plans will continue to be scrutinized. The approval plan still plays a vital role in monographic acquisitions, but integration of e-books into the approval plan enables better oversight of purchases, control of potential duplication and ability to streamline workflow. Furthermore, as space is a concern for many research libraries, implementation of an e-preferred plan reduces the number of print monographs acquired on approval. In FY 2010, prior to the adoption of an e-preferred approval plan, TAMU Libraries' weekly approval shipments averaged 622 titles. In FY 2011, after the e-preferred plan was fully operational, the weekly average fell to 286 titles. The number of e-books acquired with the e-preferred approval plan in FY 2011 totaled 2,163 titles, while only 222 titles were purchased in FY 2010 prior to the implementation of the e-preferred plan.

As studies have indicated, approval plans require consistent and regular assessment. Understanding key factors that impact approval plan expenditures will help libraries develop strategic directions for ongoing purchases. Analysis of approval plan publisher lists was crucial to the overall success in decreasing the TAMU Libraries' approval expenditure. Blocking and requiring notifications rather than automatic shipping from certain publishers also advanced TAMU Libraries' goal to mitigate duplication, eliminate marginal content, and provide a snapshot of ongoing publisher practices that impede e-book access and purchase options. (See table 4 for overall approval plan expenditure changes following the evaluation.) Although TAMU Libraries had made significant investments in the comprehensive e-book agreements, the library opted to allow those agreements to expire. This decision gives collections personnel more flexibility to reallocate monies to fund other collection initiatives (such as expanding the library's patrondriven acquisitions model). In addition, TAMU Libraries was transitioning from the "just in case" philosophy to "just in time" as budget cuts could become a more frequent occurrence.

Barriers still persist in the e-book marketplace; these barriers are mirrored in an e-preferred approval plan. Publishers still limit access to e-books by offering ebooks as single user instead of adopting a multiuser model. If the title is only sold as single user, a library still has to purchase additional copies if there is user demand. This mimics a common library practice to acquire multiple copies of a heavily referenced or used print monographic work. Since technology supports multiuser access, publishers should adopt a multiuser model as the standard acquisitions model and determine appropriate pricing that can be sustained by libraries. It is also unclear how publishers determine access models for their content.

Licensing continues to dominate all e-content purchases. With an e-preferred plan, there will be instances when the publisher requires a license for an individual title. Since TAMU Libraries has negotiated many e-book agreements over time, this has not been a frequent occurrence. However, libraries that have not invested in a licensing infrastructure should consider current workflows for processing e-book agreements and determine if e-book licenses will be managed by electronic resources librarians or acquisitions monographs personnel. YBP as an aggregator service provides some support in this area by providing licenses on file so if a license is necessary, the library can request a license that identifies YBP as the vendor. Licenses for the large e-book aggregators, such as Ebrary, EBL, and EBSCOHost, can be 
negotiated by the library at the beginning of the e-preferred plan implementation, thereby saving time when the plan begins to identify titles that fit the library's approval plan profile.

Publishers still do not systematically release electronic and print monographs simultaneously, although some progress is being made in this area. This time-lag prohibits the comprehensiveness of an e-approval plan and limits libraries' ability to minimize duplication. Libraries wanting to support users' ability to download and access e-book on mobile devices will find that most publishers permit chapter downloads while restricting the ability to download the entire book. In addition, not all e-books can be downloaded on all mobile devices. If downloading is permissible and if the e-book is accessible only to a single user, the title is taken out of circulation if one user downloads the title. In this scenario, libraries have to determine if purchasing another single-user access ebook is logical or cost-efficient to permit other users the opportunity to access the e-book. The adoption of multiuser access model by publishers would alleviate such restrictions.

\begin{tabular}{|l|c|c|c|c|}
\hline \multicolumn{5}{|c|}{ YBP Approval Plan FY Expenditures 2010-2011 } \\
\hline & $\begin{array}{c}\text { FY 2010 } \\
\text { LC Call Number }\end{array}$ & $\begin{array}{c}\text { FY 2011 } \\
\text { Expenditure }\end{array}$ & $\begin{array}{c}\text { FY } \\
\text { Expenditure } \\
\text { Difference }\end{array}$ & $\begin{array}{c}\text { Expenditure } \\
\text { Percent } \\
\text { Decrease }\end{array}$ \\
\hline A - General Works & $\$ 1,577.27$ & $\$ 1,119.28$ & $\$ 457.99$ & $-29 \%$ \\
\hline B - Philosophy & $\$ 168,616.02$ & $\$ 85,774.94$ & $\$ 82,841.08$ & $-49 \%$ \\
\hline C - History, Auxiliary Sciences & $\$ 8,189.11$ & $\$ 4,974.92$ & $\$ 3,214.19$ & $-39 \%$ \\
\hline D - History, Eastern Hemisphere & $\$ 120,996.08$ & $\$ 74,231.23$ & $\$ 46,764.85$ & $-39 \%$ \\
\hline E - History, North America & $\$ 36,985.39$ & $\$ 27,069.70$ & $\$ 9,915.69$ & $-27 \%$ \\
\hline F - History, Western Hemisphere & $\$ 17,970.42$ & $\$ 12,938.34$ & $\$ 5,032.08$ & $-28 \%$ \\
\hline G - Geography & $\$ 60,506.57$ & $\$ 43,902.33$ & $\$ 16,604.24$ & $-27 \%$ \\
\hline H - Social Sciences & $\$ 336,634.89$ & $\$ 191,034.96$ & $\$ 145,599.93$ & $-43 \%$ \\
\hline J - Political Science & $\$ 83,624.88$ & $\$ 54,541.89$ & $\$ 29,082.99$ & $-35 \%$ \\
\hline K - Law & $\$ 40,357.69$ & $\$ 14,526.06$ & $\$ 25,831.63$ & $-64 \%$ \\
\hline L - Education & $\$ 94,256.64$ & $\$ 62,690.73$ & $\$ 31,565.91$ & $-33 \%$ \\
\hline M - Music & $\$ 30,060.50$ & $\$ 11,193.68$ & $\$ 18,866.82$ & $-63 \%$ \\
\hline N - Visual Arts & $\$ 119,570.81$ & $\$ 83,821.20$ & $\$ 35,749.61$ & $-30 \%$ \\
\hline P - Philology \& Linguistics & $\$ 298,497.61$ & $\$ 194,152.45$ & $\$ 104,345.16$ & $-35 \%$ \\
\hline Q - Science & $\$ 251,425.54$ & $\$ 94,764.60$ & $\$ 156,660.94$ & $-62 \%$ \\
\hline R - Medicine & $\$ 27,485.53$ & $\$ 4,152.77$ & $\$ 23,332.76$ & $-85 \%$ \\
\hline S - Agriculture & $\$ 31,937.82$ & $\$ 6,293.83$ & $\$ 25,643.99$ & $-80 \%$ \\
\hline T - Technology & $\$ 228,994.97$ & $\$ 122,307.13$ & $\$ 106,687.84$ & $-47 \%$ \\
\hline U - Military Science & $\$ 15,060.96$ & $\$ 7,794.07$ & $\$ 7,266.89$ & $-48 \%$ \\
\hline V - Naval Science & $\$ 2,162.47$ & $\$ 1,957.78$ & $\$ 204.69$ & $-9 \%$ \\
\hline Z - Library Science & $\$ 47,538.02$ & $\$ 7,371.16$ & $\$ 40,166.86$ & $-84 \%$ \\
\hline Total & $\$ 2,022,449.19$ & $\$ 1,106,613.05$ & $\$ 915,836.14$ & $-45 \%$ \\
\hline
\end{tabular}


Access fees are another way in which publishers attempt to steer libraries toward their native platforms. For instance, recently the TAMU Libraries received a request from a faculty member to purchase a number of e-book titles from a society publisher. Since the library does not subscribe to the society's database on the native platform, the publisher is assessing a $\$ 500$ annual fee, in addition to the cost of the e-books, until we subscribe to the database on their native platform. Ideally, e-books acquired from aggregators should automatically appear on the native publisher platform, eliminating access fees while supporting multiple access points for users. Libraries should not be penalized for selecting aggregator access to content.

Libraries are engaged in developing standards and best practices to shape the e-book marketplace. These best practices are conveyed by e-book value statements. These value statements encourage fair business models, metadata standards, interlibrary loan, and flexible access models. Examples of these statements are available online at University of California at Los Angeles (UCLA) ${ }^{28}$ and North Carolina State University. ${ }^{29}$

There are new e-book partnerships that will influence the e-book marketplace and improve e-book access. Project Muse's partnership with University Press e-book Consortium (UPeC) to create the University Press Content Consortium (UPCC) was initiated to make e-book collections of university presses and scholarly publishers available. UPCC Book Collection clearly underscores core library values: no embargoes on the release of digital editions, no DRM, unlimited downloading and printing of book chapters, accessible on mobile devices, perpetual access rights for books purchased and ILL for individual book chapters. ${ }^{30}$

The Pew Research Center's Internet \& American Life Project released a series of recent national studies surveying the public's general reading habits, their use of print books, e-books, and audiobooks, and their attitudes toward evolving book acquisition and access models. One report released in April 2012, The Rise in E-Reading, ${ }^{31}$ surveyed 2,986 Americans 16 and older between November 16 and December 21, 2011, and showed that one-fifth of American adults read an e-book in the past year. The study correlates the rise of e-book reading to Americans' ownership of tablets and e-book reading devices. This report also highlights that, demographically, "adults age 18 and older who read e-books are disproportionately likely to be under the age of 50, with higher levels of education and income." 32 Another Pew Research report, Libraries, Patrons, and E-books, ${ }^{33}$ highlights issues that patrons identified with library-held e-books. These issues are similar to those encountered by academic libraries such as wait lists due to single user access model; unavailable titles due, in part, to limited e-book coverage for some disciplines; incompatibility of file formats with mobile devices, and multiple logins for vendor platforms. An issue not well documented in the e-book literature pertains to patrons' inexperience with technology. As research and public libraries seek to serve future generations, studies of this nature provide crucial evidence of demographic data, the growing popularity of e-books and the public's shifting expectations of academic and public libraries. Publishers should also consider and adopt e-book business models that accommodate e-book value statements issued by libraries and incorporate findings from national studies, such as the Pew Reports, that document public experiences and expectations. Publishers should engage libraries in meaningful dialogues, as Maureen Sullivan, the American Library Association President, states in a recent ALA press release: "The library community demands meaningful change and creative solutions that serve libraries and our readers who rightfully expect the same access to e-books as they have to printed books." 34 


\section{Conclusion}

Approval plan services have evolved to include digital content. Although barriers persist in the e-book marketplace, research libraries should continue to advocate for improved pricing and access models by working with publishers so that they understand the importance of standardizing access models to optimize user access, eliminating restrictive or punitive library purchasing models, and discontinuing embargoes. Publishers should transition the e-book marketplace to align with e-book value statements developed by libraries, including: simultaneous format availability of frontlist titles, perpetual access, interlibrary loan, portability between reading devices, standard metadata, Americans with Disabilities (ADA) compliance, no DRM, and fair pricing models. Additional studies are needed to examine publisher purchasing models for e-books that disclose factors determining current access.

Research libraries have not adopted e-preferred approval plans on a large scale, but libraries contemplating the adoption of an e-preferred approval plan should develop a data-driven strategy to minimize duplication, evaluate current e-book agreements, and examine their current approval plan profile. By carefully planning and implementing such a strategy, TAMU Libraries successfully decreased its approval plan expenditure, implemented an e-preferred plan, and evaluated comprehensive e-book arrangements. As a result of implementing an e-preferred approval plan, weekly print approval shipments declined, mitigating ongoing space limitations; duplication was minimized, and oversight of e-books by subject selectors and collections personnel has improved. The e-preferred workflow was integrated seamlessly into other acquisitions processes. TAMU Libraries collections personnel will perform additional studies that will evaluate the relationship between the implementation of the e-preferred approval plan and use of e-books.

\section{Notes}

1. Allen Kent et al., Use of Library Materials: The University of Pittsburgh Study (New York: M. Dekker, 1979), 6.

2. Collection Development Executive Committee Task Force, Report of the Collection Development Executive Committee Task Force on Print Collection Usage Cornell University Library (Ithaca: Cornell University Library, 2010), 2, available online at http://staffweb.library.cornell.edu/system/ files/CollectionUsageTF_ReportFinal11-22-10.pdf [accessed 7 June 2012].

3. Michael Levine-Clark, "Electronic Books and the Approval Plan: Can They Work Together?" Against the Grain 19, no. 2 (Apr. 2007): 18-22.

4. Wyoma vanDuinkerken, Jane Smith, Jeanne Harrell, Leslie J. Reynolds, Sandra Tucker, and Esther Carrigan, "Creating a Flexible Fund Structure to Meet the Needs and Goals of the Library and Its Users," Library Collections, Acquisitions, \& Technical Services 32, no. 3/4 (2008): 142-49.

5. Carmelita Pickett, Jane Stephens, Rusty Kimball, Diana Ramirez, Joel Thornton, and Nancy Burford, "Revisiting an Abandoned Practice: The Death and Resurrection of Collection Development Policies," Collection Management 36, no. 3 (July 2011): 165-81.

6. Association of Research Libraries, ARL Statistics 2009-2010 (Washington: Association of Research Libraries, 2011), 40.

7. Richard Abel, "The Origin of the Library Approval Plan," Publishing Research Quarterly 11, no. 1 (Spring 1995): 46-56.

8. Susan Flood and Association of Research Libraries, "Evolution \& Status of Approval Plans. SPEC Kit 221," 1997, available online at www.arl.org/bm doc/spec-211-flyer.pdf [accessed 8 June 2012].

9. Beth E. Jacoby, "Status of Approval Plans in College Libraries," College \& Research Libraries 69, no. 3 (May 2008): 227-40.

10. Robert Alan, Tina E. Chrzastowski, Lisa German, and Lynn Wiley, "Approval Plan Profile Assessment in Two Large ARL Libraries: University of Illinois at Urbana-Champaign and Pennsylvania State University," Library Resources \& Technical Services 54, no. 2 (Apr. 2010): 64-76.

11. Rosann Bazirjian, "The Impact of Approval Plans on Acquisitions Operations and Work 
Flow," Acquisitions Librarian 8, no. 16 (Dec. 1996): 29-35.

12. Flood and Association of Research Libraries, "Evolution \& Status of Approval Plans."

13. Audrey Fenner, "The Approval Plan: Selection Aid, Selection Substitute," Acquisitions Librarian 16, no. 31 (Jan. 2004): 227-40.

14. Levine-Clark, "Electronic Books and the Approval Plan," 18-22; Dracine Hodges, Cyndi Preston, and Marsha J. Hamilton, "Resolving the Challenge of E-books," Collection Management 35, no. 3 (July 2010): 196-200; Matthew Buckley and Deborah Tritt, "Ebook Approval Plans: Integration to Meet User Needs," Computers in Libraries 31, no. 3 (Apr. 2011): 15-18; Carolyn Morris and Lisa Siebert, "Acquiring E-books," in No Shelf Required: E-books in Libraries, ed. Sue Polanka (Chicago: American Library Association, 2011), 108.

15. Levine-Clark, "Electronic Books and the Approval Plan," 18-22.

16. Buckley and Tritt, "Ebook Approval Plans," 15-18.

17. Hodges et al., "Resolving the Challenge of E-books," 196-200.

18. Nancy K. Herther, "21st-Century Lending Libraries: Books in a Cloud?" Searcher 19, no. 7 (Sept. 2011): 12-51; Buckley and Tritt, "Ebook Approval Plans," 15-18.

19. Herther, "21st-Century Lending Libraries," 12-51; Buckley and Tritt, "Ebook Approval Plans," 15-18; Levine-Clark, "Electronic Books and the Approval Plan," 18-22; Hodges et al., "Resolving the Challenge of E-books," 196-200.

20. Herther, "21st-Century Lending Libraries," 12-51.

21. Wouter van der Velde and Olaf Ernst, "The Future of eBooks? Will Print Disappear? An End-User Perspective," Library Hi Tech 27, no. 4 (Jan. 2009): 570-83.

22. Levine-Clark, "Electronic Books and the Approval Plan," 18-22.

23. Ibid.

24. Buckley and Tritt, “Ebook Approval Plans," 15-18.

25. Colleen Cook and Michael Maciel, "A Decade of Assessment at a Research-Extensive University Library Using LibQUAL+®," Research Library Issues no. 271 (Aug. 2010): 4-12.

26. Jane Stephens, Pauline Melgoza, and Gang Wan, "Safari Books Online: Currency, Usage and Book Release Policies of an E-book Database," Collection Building 27, no. 1 (Feb. 2008): 14-17.

27. Rusty Kimball, Gary Ives, and Kathy Jackson, "Comparative Usage of Science E-book and Print Collections at Texas A\&M University Libraries," Collection Management 35, no. 1 (Jan. 2010): 15-28.

28. University of California at Los Angeles Library, “UCLA Library E-book Value Statement,” 2012, available online at www.library.ucla.edu/libraries/managing-collections [accessed 25 September 2012].

29. North Carolina State University Libraries, "NCSU Libraries Value Statement for the Scholarly Ebook Marketplace," available online at www.lib.ncsu.edu/cdsc/ebooks [accessed 25 September 2012].

30. Project MUSE, “UPCC Books on Project MUSE," available online at

http://muse.jhu.edu/about/UPCC.html\#title_lists [accessed 25 September 2012].

31. Lee Rainie, Kathryn Zickuhr, Kristen Purcell, Mary Madden, Joanna Brenner, and Project Pew Internet \& American Life, The Rise of E-Reading (Washington: Pew Research Center's Internet \& American Life Project, 2012), 3, available online at http://libraries.pewinternet.org/files/legacypdf/The\%20rise\%20of\%20e-reading\%204.5.12.pdf [accessed 25 September 2012].

32. Rainie et al., The Rise of E-Reading, 39.

33. Kathryn Zickuhr, Lee Rainie, Kristen Purcell, Mary Madden, Joanna Brenner, and Project Pew Internet \& American Life, Libraries, Patrons, and E-Books (Washington: Pew Research Center's Internet \& American Life Project, 2012), 53-58, available online at http://libraries.pewinternet.org/ files/legacy-pdf/PIP_Libraries_and_Ebook_Patrons\%206.22.12.pdf [accessed 25 September 2012].

34. American Library Association, "An Open Letter to America's Publishers from ALA President Maureen Sullivan," 2012, available online at www.ala.org/news/pr?id=11508 [accessed 25 September 2012]. 